\title{
Penerapan Terapi Generalis, Terapi Aktivitas Kelompok Sosialisasi, dan Social Skill Training pada Pasien Isolasi Sosial
}

\author{
Zakiyah $^{1}$, Achir Yani S. Hamid ${ }^{2}$, Herni Susanti ${ }^{3}$ \\ ${ }^{1}$ Program Studi Ilmu Keperawatan STIKes Binawan, Jl. Kalibata Raya No. 25-30 \\ ${ }^{2,3}$ Departemen Keperawatan Jiwa Fakultas Ilmu Keperawatan Universitas Indonesia, \\ Jalan Prof. Dr. Bahder Djohan Depok 16424 \\ Email: zakiyah.mista@gmail.com
}

Diterima: 27 Agustus 2018

Disetujui: 28 September 2018

\begin{abstract}
Abstrak
Latar Belakang:Isolasi sosial merupakan salah satu gejala negatif skizofrenia. Isolasi Isolasi sosial adalah kondisi menyendiri yang dialami seseorang dan perasaan segan terhadap orang lain sebagai sesuatu yang negatif atau keadaan yang mengancam. Masalah sosial seringkali merupakan sumber utama keprihatinan keluarga dan penyedia layanan kesehatan, karena efeknya lebih menonjol daripada gejala kognitif dan persepsi.

Tujuan: Penelitian ini bertujuan untuk menggambarkan penerapan Terapi Generalis (TG), Terapi Aktivitas Kelompok Sosialisasi (TAKS), dan Social Skill Training (SST) pada pasien isolasi sosial.

Metode: Metodelogi Penelitian ini adalah deskriptif kuantitatif melalui stusi kasus kepada 35 pasien di ruang Bratasena Rumah Sakit dr. H. Marzoeki Mahdi Bogor. Tanda dan Gejala isolasi sosial diidentifikasi sebelum dan setelah penerapan GT, TAKS, dan SST menggunakan instrument tanda dan gejala isolasi social yang dimodifikasi terdiri dari aspek kognitif, afektif, fisiologis, perilaku, dan social.

Hasil: Hasil penelitian menunjukkan ada penurunan tanda dan gejala isolasi social (75,75\%), dan peningkatan kemampuan pasien dalam bersosialisasi (TG: 68,57\%, TAKS: 83,90\%, SST: 70,29\%).

Simpulan: Berdasarkan hasil dari penerapan ketiga terapi diatas, perlu direkomendasikan integrasi tindakan keperawatan generalis individu dan kelompok serta terapi spesialis social skill training pada pasien isolasi social agar perawatan pasien dengan isolasi sosial efektif.
\end{abstract}

Kata Kunci: skizofrenia; isolasi sosial; terapi generalis; terapi aktivitas kelompok; social skill training

Rujukan artikel penelitian:

Zakiyah, Hamid, A. Y. S., Susanti, H. (2018). Penerapan Terapi Generalis, Terapi Aktivitas Kelompok Sosialisasi, dan Social Skill Training pada Pasien Isolasi Sosial. Jurnal Ilmiah Keperawatan Indonesia. Vol. 2 (1): 19- 32. 
The Implementation of Generalist Therapy, Group Activity Therapy, and Social Skill

Training in Social Isolation Patients

\begin{abstract}
Background: Social isolation is one of negative symptoms of schizophrenia. Social isolation as a solitary experience of a person and shyness toward others as something negative or threatening circumstances. Social problems are often a major source of concern families and health care providers, because the effect of social isolation is more pronounced than cognitive and perception symptoms.

Aim: The purpose of this study was describe the implementation of General Therapy (GT), Socialization Activity Group Therapy (SAGT) and Social Skill Training (SST) toward social isolation clients.

Methods: The methodelogy of this study was quantitative descriptive using case study to 35 selected clients at Bratasena's ward dr. Marzoeki Mahdi Bogor Hospital. Sign and symptoms of social isolation identified before and after implementation of GT, SAGT, and SST using modified social isolation mark and symptoms that consisted cognitive, affective, psysiological, behavior, and social aspects.

Results: there were reductions in symptoms of social isolation $(75,75 \%)$ and increase in the client's ability to socialize (GT:68,57\%), SAGT: 83,90\%, SST: 70,29\%).

Conclusion: Based on the result of the implementations, it is recommended to integrate the general therapy, socialization activity group therapy and social skill training in order to make an effective social isolation care.
\end{abstract}

Key Words: Schizophrenia; social isolation; general therapy; activity group therapy; social skill training.

\title{
PENDAHULUAN
}

Orang Dengan Gangguan Jiwa (ODGJ) merupakan salah satu masalah kesehatan jiwa berat di Indonesia. Riskesdas (2007) menyebutkan prevalensi gangguan jiwa berat di Indonesia adalah 4,6 permil, dan Riskesdas 2013 menyebutkan prevalensi gangguan jiwa berat Indonesia sebesar 1,7 permil. Pasien gangguan jiwa berat terbesar di Indonesia adalah Skizofrenia yakni $70 \%$ (Balitbang Depkes RI, 2008). Kelompok skizofrenia juga menempati 90\% pasien di rumah sakit Jiwa di seluruh Indonesia (Jalil, 2006). Di Rumah Sakit Marzoeki Mahdi (RSMM) Bogor semester I Tahun 2016, angka pasien skizofrenia menempati urutan pertama di unit rawat jalan psikiatri, unit rawat inap psikiatri, dan Instalasi Gawat Darurat psikiatri. 
Stuart (2016) menyebutkan kebanyakan orang dengan gangguan jiwa berat terisolasi dari sekitarnya dan kesulitan memiliki serta menjaga hubungannya dengan orang lain. Videbeck (2011) menyebutkan bahwa isolasi sosial sering terlihat pada pasien skizofrenia.

Skizofrenia adalah penyakit otak neurobiologis yang berat dan terus menerus (Stuart, 2016), dimana gejala skizofrenia dibagi dalam dua kategori utama: gejala positif atau gejala nyata, yang mencakup waham, halusinasi, dan disorganisasi pikiran, bicara, dan perilaku yang tidak teratur, serta gejala negatif atau gejala samar, seperti afek datar, tidak memiliki kemauan, dan menarik diri dari masyarakat atau rasa tidak nyaman (Videbeck, 2011). Gejala negatif menarik diri dari masyarakat dan disfungsi sosial merupakan konsekuensi hubungan respon neurobiologis maladaptif. Stuart (2016) menyebutkan masalah sosial seringkali merupakan sumber utama keprihatian keluarga dan penyedia layanan kesehatan. Perilaku langsung dari masalah sosial meliputi ketidakmampuan untuk berkomunikasi koheren, hilangnya dorongan dan ketertarikan, penurunan keterampilan sosial, kebersihan pribadi yang buruk, dan paranoid. Perilaku lain yang terjadi adalah harga diri rendah berhubungan dengan prestasi akademik dan sosial yang buruk, merasakan ketidaknyamanan, dan yang paling sering terjadi adalah isolasi sosia.

Isolasi sosial adalah suatu pengalaman menyendiri dari seseorang dan perasaan segan terhadap orang lain sebagai sesuatu yang negatif atau keadaan yang mengancam (NANDA, 2015-2017). Ancaman yang dirasakan dapat menimbulkan respons. Respon kognitif pasien isolasi sosial dapat berupa merasa ditolak oleh orang lain, merasa tidak dimengerti oleh orang lain, merasa tidak berguna, merasa putus asa dan tidak mampu membuat tujuan hidup atau tidak memiliki tujuan hidup, tidak yakin dapat melangsungkan hidup, kehilangan rasa tertarik kegiatan sosial, merasa tidak aman berada diantara orang lain, serta tidak mampu konsentrasi dan membuat keputusan.

Respon afektif pasien dengan masalah keperawatan isolasi sosial berupa merasa bosan, afek tumpul, dan kurang motivasi. Respon fisiologis yang terjadi pada pasien isolasi sosial berupa wajah murung, sulit tidur, gelisah, lemah, kurang bergairah, dan malas beraktivitas. Respon perilaku pasien isolasi sosial 
ditunjukkan dengan pasien menarik diri, menjauh dari orang lain, tidak atau jarang melakukan komunikasi tidak ada kontak mata, kehilangan minat, malas melakukan kegiatan sehari-sehari atau aktivitas sosial, berdiam diri di kamar, menolak hubungan dengan orang lain, dan tidak mau menjalin persahabatan. Respon Sosial yang dapat ditemukan pada pasien isolasi sosial berupa ketidakmampuan berkomunikasi dengan orang lain, acuh dengan lingkungan, kemampuan sosial menurun, dan sulit berinteraksi (Stuart, 2013; Townsend, 2009).

Tindakan keperawatan yang dapat diberikan kepada pasien dengan masalah isolasi sosial adalah tindakan keperawatan Generalis, Terapi Aktivitas Kelompok Sosialisasi (TAKS), dan psikoterapi sebagai terapi spesialis dalam hal ini Social Skill Training (SST). Terapi generalis sosialisasi individu pada pasien isolasi sosial berpengaruh terhadap perubahan perilaku isolasi sosial pada pasien skizofenia (Nurfitiana, 2011). Terapi aktivitas kelompok memiliki pengaruh terhadap peningkatan keterampilan sosial dasar pada pasien skizofrenia dengan adanya kenaikan skor keterampilan dasar dan masing-masing subyek merasakan manfaat dari terapi aktivias kelompok (Hartono, 2015). SST memiliki pengaruh positif terhadap kesulitan interpersonal, gejala depresi, dan harga diri rendah pada pasien skizofrenia. SST dapat meningkatkan kemampuan interpersonal, harga diri, dan menurunkan gejala depresi pada pasien skizofrenia (El Malky, Attia, \& Alam, 2016). Penelitian lainnya dilakukan oleh Renidayati, Keliat, dan Helena (2008) menunjukkan hasil bahwa SST memberikan pengaruh terhadap peningkatan kemampuan bersosialisasi pada pasien dengan isolasi sosial di rumah sakit jiwa. Pemberian tindakan generalis pasien, TAKS, tindakan generalis keluarga, latihan keterampilan sosial dan psikoedukasi pada keluarga lebih tinggi penurunan tanda dan gejala serta peningkatan kemampuan sosialisasi dibandingkan yang tidak diberikan tindakan keperawatan generalis pasien, TAKS, generalis keluarga dan latihan keterampilan sosial (Martina, Keliat, \& Putri, 2014). Berdasarkan hal tersebut, penelitian ini dilakukan untuk mengetahui dampak pemberian tiga terapi (terapi generalis, terapi aktivitas kelompok sosialisasi, dan social skill training) terhadap penurunan tanda dan gejala dan kemampuan pasien skizofrenia yang mengalami isolasi social. 


\section{BAHAN DAN METODE}

Penelitian dilakukan dengan menggunakan metode deskriptif kuantitatif melalui studi kasus dengan menerapkan terapi generalis, TAKS, dan SST kepada 35 pasien isolasi sosial di ruang Bratasena RSMM Bogor, mulai tanggal 13 September-18 November 2016. Bahan yang digunakan untuk mengidentifikasi tanda dan gejala isolasi sosial sebelum dan sesudah penerapan terapi generalis, TAKS, dan SST menggunakan instrument tanda dan gejala isolasi sosial yang dimodifikasi dari berbagai sumber. Jumlah item pertanyaan 33 item yang terdiri dari 7 item aspek kognitif, 8 item aspek afektif, 4 item aspek fisiologis, 7 item aspek perilaku, dan 7 item aspek sosial.

Penerapan terapi generalis dilakukan pada 35 pasien dengan melibatkan Perawat Penanggung Jawab Pasien (PPJP) dan mahasiswa praktikan D3 keperawatan dan Ners yang bertanggung jawab terhadap masing-masing pasien. Penerapan terapi generalis menggunakan pedoman asuhan keperawatan diagnosa gangguan jiwa dengan pendekatan Strategi Pelaksanan (SP) yang ditetapkan di RSMM. SP yang dilakukan pada pasien masing-masing terdiri dari 4 (empat) SP. Pertama, melatih pasien mengenal masalah isolasi sosial; kedua, melatih pasien berkenalan dengan perawat atau pasien lain; ketiga, melatih pasien berkenalan dengan 2 orang atau lebih; keempat, berinteraksi dengan kelompok. Jumlah pertemuan terapi generalis pada masing-masing pasien berbeda. Hal ini dipengaruhi oleh kondisi dan kemampuan tiap pasien yang berbeda. Selama penerapan terapi generalis, peran sebagai narasumber dan pendidik sering dilakukan, dimana informasi yang pernah didapatkan pasien pada perawatan sebelumnya dan di ruang perawatan sebelumnya tentang cara mengatasi isolasi sosial dieksploitasi, dilatih, dan dikembangkan setiap kali interaksi untuk membantu pasien menyelesaikan masalahnya secara mandiri.

Penerapan TAKS juga dilakukan pada 35 pasien isolasi sosial . 35 pasien yang dilakukan TAKS sebelumnya telah diseleksi dan memenuhi persyaratan untuk mengikuti TAKS, pasien setidaknya telah dilakukan SP 1 dan SP 2 terapi generalis. Hal ini dilakukan agar terapi yang dilakukan terintegrasi, efektif dan waktu yang dibutuhkan untuk mengatasi masalah pasien lebih cepat. Pelaksanaan TAKS dilakukan selama 5-6 hari setiap minggunya pada satu kelompok yang 
terdiri dari 6-7 pasien isolasi sosial. TAKS yang dilakukan terdiri dari 7 sesi sesuai dengan panduan TAKS yang dibuat oleh Keliat \& Akemat (2010). Sesi 1 dan 2 dilakukan pada satu kali pertemuan, dilanjutkan dengan sesi berikutnya sampai sesi 7. Selama penerapan TAKS, peran sebagai pemimpin dan narasumber sering dilakukan untuk memimpin, membantu dan memfasilitasi pasien untuk berpartisipasi secara aktif dan demokratis dalam kegiatan kelompok dan memberikan informasi yang dibutuhkan setiap anggota kelompok TAKS selama TAKS berlangsung.

Penerapan SST juga dilakukan pada 35 pasien isolasi social dengan mengacu pada Modul Terapi Keperawatan Jiwa (2016). Jumlah pertemuan terapi pada tiap pasien berbeda tergantung kemampuan pasien dalam memahami proses terapi. SST yang terdiri dari 4 sesi latihan, maksimal dilakukan 6 kali pertemuan. Sesi pertama melatih pasien berkenalan dengan sikap dan cara bicara yang baik dan jelas. Sesi kedua melatih pasien menjalin persahabatan, sesi ini yang memerlukan jumlah pertemuan lebih banyak oleh sebagian besar pasien, sesi ketiga melatih pasien untuk bekerjasama dalam kelompok. sesi ini juga memerlukan latihan berulang-ulang sehingga pasien mampu melakukannya secara alamiah. Pemberian terapi SST dilakukan dengan mengintegrasikan pelaksanaan SP pada terapi generalis, minimal setelah pasien mampu mengenal masalah isolasi sosial dan memperkenalkan diri dengan perawat atau pasien lain, baik individu maupun dalam kelompok melalui TAKS.

\section{HASIL DAN BAHASAN}

Hasil dari tahap identifikasi didapatkan karakteristik pasien semuanya berjenis kelamin laki-laki (100\%), berusia dewasa (89\%), berpendidikan SD $(28,57 \%)$, tidak bekerja (89\%), belum/tidak kawin (69\%), sakit > 5 tahun $(51 \%)$, dan pertama kali dirawat di RSMM (46\%). Penyebab pasien dirawat dari faktor biologis adalah riwayat gangguan jiwa sebelumnya (91,43\%), penyebab psikologis adalah konsep diri yang negatif $(77,14 \%)$, dan penyebab sosio kultural karena penghasilan kurang (94,29\%). Faktor pencetus pasien dirawat dari aspek biologis adalah putus obat $(88,57 \%)$ pencetus psikologis terbanyak adalah 
pengalaman yang tidak menyenangkan (100\%),dan pencetus sosiokultural adalah penghasilan kurang $(97,14 \%)$.

Tanda dan gejala yang dilihat pada pasien terdiri dari aspek kognitif, afektif, fisiologis, perilaku, dan sosial. Hasil identifikasi didapatkan tanda dan gejala kognitif pasien adalah tidak mampu menerima nilai dari orang lain, tidak mampu memenuhi harapan dari orang lain, dan tidak mampu membuat tujuan hidup (91\%), tanda dan gejala afektif pasien memiliki afek datar (86\%), tanda dan gejala fisiologis pasien memiliki kurang bergairah (97\%), tanda dan gejala perilaku pasien adalah negativism, banyak melamun, dan dipenuhi dengan pikiran sendiri ( $94 \%$ ), tanda dan gejala sosial yang paling menonjol adalah acuh terhadap lingkungan (94\%).

Setelah diberikan terapi generalis, TAKS, dan SST pada pasien terjadi perubahan pada tanda dan gejala isolasi sosial dan peningkatan kemampuan pasien dalam bersosialisasi. Perubahan tanda dan gejala isolasi sosial sebelum dan setelah diberikan terapi dapat dilihat pada tabel 1. Perubahan kemampuan pasien dalam bersosialisasi sebelum dan setelah diberikan terapi generalis dapat dilihat pada tabel 2, perubahan kemampuan pasien sebelum dan setelah diberikan terapi aktivitas kelompok sosialisasi dapat dilihat pada tabel 3, dan Perubahan kemampuan pasien dalam bersosialisasi sebelum dan setelah diberikan social skill training dapat dilihat pada tabel 4.

\section{Tabel 1}

Perubahan Tanda dan Gejala isolasi Sosial

\begin{tabular}{llllllcl}
\hline No & Tanda \& Gejala & Pre & $\%$ & Post & $\%$ & Penurunan & $\%$ \\
\hline 1 & Kogitif & 5,4 & 77,14 & 1,55 & 22,14 & 3,85 & 71,30 \\
\hline 2 & Afektif & 4,23 & 52,88 & 0,99 & 12,38 & 3,29 & 77,78 \\
\hline 3 & Fisiologis & 2,51 & 62,75 & 0,85 & 2,43 & 1,65 & 65,73 \\
\hline 4 & Perilaku & 5,51 & 78,71 & 1,51 & 21,57 & 4 & 72,60 \\
\hline 5 & Sosial & 5,31 & 75,86 & 0,45 & 6,43 & 4,85 & 91,33 \\
\hline & Total & $\mathbf{2 2 , 9 6}$ & $\mathbf{6 9 , 4 7}$ & $\mathbf{5 , 3 5}$ & $\mathbf{1 2 , 9 9}$ & $\mathbf{1 7 . 6 4}$ & $\mathbf{7 5 , 7 5}$ \\
\hline
\end{tabular}


Tabel 2

Kemampua Pasien dalam Terapi Generalis

\begin{tabular}{|c|c|c|c|c|c|c|c|}
\hline No & Kemampuan & Pre & $\%$ & Post & $\%$ & Peningkatan & $\%$ \\
\hline 1 & $\begin{array}{l}\text { Mengidentifikasi penyebab isolasi } \\
\text { sosial }\end{array}$ & 23 & 66 & 33 & 94 & 10 & 29 \\
\hline 2 & $\begin{array}{l}\text { Menyebutkan Keuntungan } \\
\text { berinteraksi }\end{array}$ & 8 & 23 & 31 & 89 & 23 & 66 \\
\hline 3 & Berkenalan & 22 & 63 & 35 & 100 & 13 & 37 \\
\hline 4 & $\begin{array}{l}\text { Berbicara dengan orang lain saat } \\
\text { melakukan aktifitas }\end{array}$ & 1 & 3 & 34 & 97 & 33 & 94 \\
\hline 5 & $\begin{array}{l}\text { Berbicara dengan lebih dari } 2 \\
\text { orang dalam kegiatan kelompok }\end{array}$ & 0 & 0 & 34 & 97 & 34 & 97 \\
\hline 6 & $\begin{array}{l}\text { Berbicara sosial saat meminta } \\
\text { sesuatu dan menjawab pertanyaan }\end{array}$ & 4 & 11 & 35 & 100 & 31 & 89 \\
\hline & Rata-rata & $\mathbf{9 , 7}$ & 27,71 & $\mathbf{3 3 , 7}$ & 96,29 & 24 & 68,57 \\
\hline
\end{tabular}

Tabel 3

Kemampuan Pasien dalam Terapi Aktivitas Kelompok

\begin{tabular}{llllllcc}
\hline No & Kemampuan & Pre & $\%$ & Post & $\%$ & Peningkatan & $\%$ \\
\hline 1 & Memperkenalkan Diri & 13 & 31,14 & 35 & 100 & 22 & 62,85 \\
\hline 2 & Berkenalan & 13 & 31,14 & 35 & 100 & 22 & 62,85 \\
\hline 3 & Bercakap-cakap & 6 & 17,14 & 32 & 91,43 & 26 & 81,25 \\
\hline 4 & Bercakap-cakap topik tertentu & 1 & 2,85 & 28 & 80 & 27 & 96,43 \\
\hline 5 & $\begin{array}{l}\text { Bercakap-cakap masalah } \\
\text { pribadi }\end{array}$ & 0 & 0 & 26 & 74,29 & 26 & 74,29 \\
\hline 6 & Bekerjasama & 0 & 0 & 31 & 88,57 & 31 & 88,57 \\
\hline \multicolumn{2}{c}{ Rata-rata } & $\mathbf{5 , 5}$ & $\mathbf{1 3 , 7 2}$ & $\mathbf{3 1 , 1 7}$ & $\mathbf{8 9 , 0 4}$ & $\mathbf{2 5 , 6 7}$ & $\mathbf{8 3 , 9 0}$ \\
\hline
\end{tabular}

Tabel 4

Kemampuan Pasien dalam Social Skill Training

\begin{tabular}{llllll}
\hline No Kemampuan & Pre & $\%$ & Post & Peningkatan $\%$
\end{tabular}

\begin{tabular}{|c|c|c|c|c|c|c|c|}
\hline 1 & Bersosialisasi & 10,23 & 29,23 & 33,23 & 94,95 & 23 & 65,71 \\
\hline 2 & Menjalin Persahabatan & 0,21 & 0,6 & 28,58 & 81,65 & 28,37 & 81,05 \\
\hline 3 & $\begin{array}{ll}\text { Bekerjasama } & \text { dalam } \\
\text { kelompok } & \\
\end{array}$ & 0 & 0 & 25 & 71,43 & 25 & 71,43 \\
\hline 4 & Menghadapi situasi sulit & 0 & 0 & 22 & 62,85 & 22 & 62,85 \\
\hline & Rata-rata & 2,61 & $\mathbf{0 , 7 5}$ & 27,21 & 77,75 & 24,60 & 70,29 \\
\hline
\end{tabular}


Dari keempat tabel di atas menunjukkan bahwa terapi generalis, TAKS, dan SST dapat menurunkan tanda dan gejala isolasi sosial dan meningkatkan kemampuan pasien dalam bersosialisasi.

\section{Bahasan}

Hasil pelaksanaan terapi generalis, TAKS, dan SST menunjukkan adanya penurunan terhadap tanda dan gejala isolasi sosial dan meningkatkan kemampuan pasien. Penerapan terapi generalis dilakukan pada 35 pasien dengan melibatkan PPJP dan mahasiswa D3 dan Ners yang bertanggung jawab terhadap masingmasing pasien. Penerapan terapi generalis menggunakan pedoman asuhan keperawatan diagnosa gangguan jiwa dengan pendekatan Strategi Pelaksanan (SP) yang ditetapkan di RSMM. SP yang dilakukan pada pasien masing-masing terdiri dari 4 (empat) SP. Pertama, melatih pasien mengenal masalah isolasi sosial; kedua, melatih pasien berkenalan dengan perawat atau pasien lain; ketiga, melatih pasien berkenalan dengan 2 orang atau lebih; keempat, berinteraksi dengan kelompok. Jumlah pertemuan terapi generalis pada masing-masing pasien berbeda. Hal ini dipengaruhi oleh kondisi dan kemampuan tiap pasien yang berbeda.

Penerapan TAKS juga dilakukan pada 35 pasien isolasi sosial. Stuart (2016) menyebutkan kelompok menawarkan berbagai hubungan antara anggota karena setiap anggota kelompok akan berinteraksi satu sama lain dengan pemimpin kelompok. anggota kelompok berasal dari berbagai latar belakang dan masing-masing memiliki kesempatan untuk belajar dari orang lain di luar lingkaran sosialnya. 35 pasien yang dilakukan TAKS sebelumnya telah diseleksi dan memenuhi persyaratan untuk mengikuti TAKS, pasien setidaknya telah dilakukan SP 1 dan SP 2 terapi generalis. Hal ini dilakukan agar terapi yang dilakukan terintegrasi, efektif dan waktu yang dibutuhkan untuk mengatasi masalah pasien lebih cepat. Terapi generalis pada pasien isolasi sosial ditujukan untuk melatih keterampilan sosial pasien sehingga merasa nyaman dalam situasi sosial dan dapat melakukan interaksi sosial dengan orang lain serta lingkungannya. Keliat, dkk (2011) menambahkan bahwa tujuan yang diharapkan setelah dilakukan tindakan generalis, pasien mampu membina hubungan saling 
percaya dengan orang lain, menyadari penyebab isolasi sosial dan mampu berinteraksi dengan orang lain secara bertahap. Terapi generalis sosialisasi individu pada pasien isolasi sosial berpengaruh terhadap perubahan perilaku isolasi sosial pada pasien skizofrenia (Nurfitriana, 2011).

Pelaksanaan TAKS dilakukan selama 5-6 hari setiap minggunya pada satu kelompok pasien isolasi sosial. TAKS yang dilakukan terdiri dari 7 sesi sesuai dengan panduan TAKS yang dibuat oleh Keliat \& Akemat (2010). Sesi 1 dan 2 dilakukan pada satu kali pertemuan, dilanjutkan dengan sesi berikutnya sampai sesi 7. Selama penerapan TAKS, penulis banyak berperan sebagai pemimpin dan narasumber, yang membantu dan memfasilitasi pasien untuk berpartisipasi secara aktif dan demokratis dalam kegiatan kelompok dan memberikan informasi yang dibutuhkan setiap anggota kelompok TAKS selama TAKS berlangsung. Perawat yang merupakan pemimpin kelompok harus dapat mempelajari kelompok dan berpartisipasi di dalamnya pada waktu yang bersamaan. Pemimpin harus selalu memantau kelompok, dan bila diperlukan, membantu kelompok mencapai tujuannya (Stuart, 2016). Terapi dalam bentuk kelompok cukup efektif bagi pasien yang sudah mampu berinteraksi dengan lingkungannya meskipun minimal. Peran kelompok adalah membantu dalam penyelesaian masalah dan pengambilan keputusan (Fontaine, 2009). Hartono (2015) dalam penilitiannya mendapatkan bahwa terapi aktivitas kelompok memiliki pengaruh terhadap peningkatan keterampilan sosial dasar pada pasien skizofrenia dengan adanya kenaikan skor keterampilan dasar dan masing-masing subyek merasakan manfaat dari terapi aktivitas kelompok.

Penerapan SST juga dilakukan pada 35 pasien isolasi sosial. Jumlah pertemuan terapi pada tiap pasien berbeda tergantung kemampuan pasien dalam memahami proses pembelajaran. SST yang terdiri dari 4 sesi latihan, maksimal dilakukan 6 kali pertemuan. Sesi yang memerlukan jumlah pertemuan lebih banyak oleh sebagian besar pasien adalah sesi dua (menjalin persahabatan) dan sesi tiga (bekerjasama dalam kelompok). Kedua sesi tersebut memerlukan latihan berulang-ulang sehingga pasien mampu melakukannya secara alamiah. Pemberian terapi SST dilakukan dengan mengintegrasikan pelaksanaan SP pada terapi generalis, minimal setelah pasien mampu mengenal masalah isolasi sosial dan 
memperkenalkan diri dengan perawat atau pasien lain, baik individu maupun dalam kelompok melalui TAKS. Setelah itu, pasien masuk pada terapi SST. SST dilakukan untuk meningkatkan dan membentuk komunikasi yang fleksibel sehingga pasien mampu berespons dengan baik terhadap situasi yang beragam. Peran perawat disini adalah memberikan penguatan positif, menjadi role model, tolok ukur, terapis, dan membentuk pola perilaku sosialisasi pasien yang diharapkan (El Malky, Attia, \& Alam, 2016). Perawat juga berfungsi sebagai perencana/planner dan koordinator dari berbagai program pengobatan yang diberikan pada pasien (Stuart, 2013). Selain itu SST ditujukan untuk meningkatkan ekspresi, persepsi sosial dan emosional pasien dalam melakukan ketrampilan berkomunikasi. Fokus latihan ini adalah pada latihan untuk mengenali, mengekspresikan ketidaknyamanan, menimbulkan perasaan positif, meminta maaf dan memaafkan dan berbagi ketakutan yang dirasakan. Stuart (2016) menyebutkan jenis-jenis perilaku yang sering diajarkan dalam SST antara lain mengajukan pertanyaan, memberikan pujian, membuat perubahan positif, mempertahankan kontak mata, meminta orang lain untuk mengubah perilaku tertentu, berbicara dengan nada dan suara yang jelas, dan menghindari sikap gelisah.

SST adalah terapi yang berorientasi pada tugas dan membentuk perilaku baru. Hasilnya akan efektif jika perilaku tersebut dilakukan berulang-ulang. Pengulangan tiap sesi dilakukan di ruangan masing-masing. Keberhasilan SST dalam merubah tanda gejala dan kemampuan pasien tertuang dalam beberapa karya tulis ilmiah. Sukaesti, Hamid, \& Wardani (2015) dalam tulisan ilmiahnya menunjukkan bahwa SST yang dikombinasikan dengan Family Psychoeducation (FPE) dapat menurunkan tanda dan gejala serta meningkatkan kemampuan pasien dengan halusinasi dan isolasi sosial. Tulisan ilmiah Imelisa, Hamid, \& Mustikasari (2013) menunjukkan bahwa SST dapat meningkatkan kemampuan dan menurunkan tanda dan gejala pasien isolasi sosial dengan melakukan pendekatan teori social support. Sedangkan pada penelitian Putri (2012) menunjukkan bahwa dengan SST yang dilakukan dengan pendekatan teori Peplau dan Henderson dapat memudahkan perawat dalam berinteraksi dengan pasien isolasi sosial. Tulisan Ilmiah Azizah, (2016) menunjukkan SST yang 
dikombinasikan dengan CBSST dengan pendekatan Peplau dan Henderson dapat menurunkan tanda dan gejala serta meningkatkan kemampuan pasien isolasi sosial. Tulisan Ilmiah Kirana (2016) juga menunjukkan bahwa SST dapat menurunkan tanda dan gejala serta meningkatkan kemampuan pasien isolasi sosial.

\section{SIMPULAN DAN SARAN}

Pemberian terapi Terapi Generalis, TAKS, dan SST pada pasien skizofrenia yang mengalami isolasi social dapat menurunkan tanda dan gejala isolasi sosial dan meningkatkan kemampuan pasien dalam bersosialisasi.

Dari hasil penelitian, direkomendasikan untuk memberikan perawatan pada pasien isolasi sosial dengan pendekatan secara individu, maupun kelompok melalui terapi generalis pasien, terapi aktivitas kelompok sosialisasi, dan social skill training.

\section{RUJUKAN}

Azizah, F.N., Hamid, A.Y.S., \& Wardani, I.Y. (2016).Manajemen Kasus Spesialis Keperawatan Jiwa Pada Klien Isolasi Sosial dengan Pendekatan Teori Hildegard E. Peplau dan Virginia Henderson di Ruang Utari Rumah Sakit Dr. H. Marzoeki Mahdi Bogor. Karya IlmiahAkhir. Fakultas Ilmu Keperawatan Universitas Indonesia.Tidak dipublikasikan.

El Malky, A.I., Attia, M.M., \& Alam, F.H. (2016).The Effectiveness of Social Skill Training on Depressive Symptoms, Self-esteem and Interpersonal Difficulties Among Schizophrenia Patients. International Journal of Advance Nursing Studies, 5 (1) (2016) 43-50. diunduh tanggal 1 Desember 2016.

Fontaine, K.L. (2009). Mental Health Nursing. $6^{\text {th }}$ edition.New Jersey: Pearson Education.

Hartono. (2015). Pengaruh Terapi Aktifitas Kelompok Terhadap Peningkatan Keterampilan Sosial Dasar Pada Klien Skizofrenia di RSUD Dr. RM. Soedjarwadi Propinsi Jawa Tengah Tahun 2105.EMPHATY Jurnal Fakultas Psikologi. Volume 3 Nomor 2 November 2015. Diunduh tanggal 4 Januari 2017.

Imelisa, R. Hamid, A.Y.S., \& Daulima, N.H.C. (2013).Manajemen Asuhan Keperawatan Spesialis Jiwa Pada Klien Isolasi Sosial yang Diberikan Social Skill Training Menggunakan Pendekatan Social Support Theory di RSMM 
dan Kelurahan Tanah Baru Bogor. Karya Ilmiah Akhir. Fakultas Ilmu Keperawatan UniversitasIndonesia. Tidak dipublikasikan.

Jalil, A., Hamid, Ay.,\& Mustikasari. (2014). Penerapan Acceptance and Commitment Therapy, dan Cognitive Behavioral Social Skills Training Menggunakan Pendekatan Model Adaptasi Roy dan Model Tidal Pada Klien Harga Diri Rendah Kronis dan Isolasi Sosial. Karya Ilmiah Akhir. Fakultas Ilmu Keperawatan Universitas Indonesia.Tidak dipublikasikan.

Keliat, BA., Pawirowiyono, A.(2010). Keperawatan Jiwa;Terapi Aktifitas Kelompok. edisi 2. Jakarta: EGC.

Kementrian Kesehatan Republik Indonesia; Badan Penelitian dan Pengembangan.(2008). Riset kesehatan dasar tahun 2007.http://labdata.litbang.depkes.go.id/riset-badan-litbangkes/menuriskesnas/menu-riskesdas/147-rkd-2007.

Kementrian Kesehatan Republik Indonesia; Badan Penelitian dan Pengembangan.(2013). Riset kesehatan dasar tahun 2013.http://www.depkes.go.id/resources/download/general/Hasil\%20Riskes das\%202013.pdf.

Kirana, S.A.C., Mustikasari, \& Putri, Y.S.E. (2016).Pemberian Asuhan Keperawatan Spesialis Pada Klien dengan Isolasi SOsial dalam Menurunkan Gejala dan Meningkatkan Kemampuan Melalui Pendekatan Model Konsep Hildegard E. Peplau dan Konsep Stres Adaptasi Stuart di RSMM Bogor. Karya Ilmiah Akhir. Fakultas Ilmu KeperawatanUniversitas Indonesia.Tidak dipublikasikan.

Laporan Semester I Rumah sakit dr. H. Marzoeki Mahdi Bogor Tahun 2016.http://static.rsmmbogor.com/cdn/File/semester2016.pdf.

Martina, Keliat, BA.,\& Putri, YSE. (2014). Penerapan Latihan Keterampilan Sosial dan Psikoedukasi Keluarga Pada Klien Isolasi Sosial menggunakan Pendekatan Modelling dan Role Modelling di Rumah Sakit Jiwa. Karya Ilmiah Akhir. Fakultas Ilmu Keperawatan Universitas Indonesia.Tidak dipublikasikan.

NANDA International.(2014). Diagnosis Keperawatan Definisi dan Klasifikasi 2015-2017. Cetakan I. Jakarta: Penebit Buku Kedokteran EGC.

Nurfitriana.(2011). Pengaruh Terapi Individu Sosialisasi Terhadap Perubahan Perilaku Isolasi Sosial Pada Pasien Skizofrenia di Rumah Sakit Grhasia Provinsi Daerah Istimewa Yogyakarta. Naskah Publikasi. http://lib.unisayogya.ac.id. Diunduh pada tanggal 4 Januari 2017. 
Putri, D.E. (2012). Penerapan Asuhan Keperawatan Pada Klien Isolasi SOsial dengan Pendekatan Model Konseptual Hildegard E. Peplau dan Virginia Henderson. Ners Jurnal Keperawatan. Volume 8.Nomor 1.

Renidayati, Keliat, B.A., Helena, N.C.D. (2008). Pengaruh Terapi Social Skill Training Pada Klein Isolasi Sosial di RS Jiwa Prof HB Saanin, Padang Sumatera Barat.Tesis.Fakultas Ilmu Keperawatan Universitas Indonesia.Tidak dipublikasikan.

Renidayati, Nurjanah,S., Rosiana, A., Pinilih, S., \& Tim FIK UI. (2016). Modul Terapi Keperawatan Jiwa. Workshop Keperawatan Jiwa X. Fakultas Ilmu Keperawatan Universitas Indonesia.Tidak dipublikasikan.

Stuart, Gail W. (2013). Principles \& Practice of Psychiatric Nursing. $8^{\text {th }}$ ed. Philadelphia: Elsevier Mosby.

Stuart, Gail W. (2016). Prinsip dan Praktik Keperawatan Kesehatan jiwa Stuart.Edisi Indonesia.Buku 1 \& 2. Singapura: Elsevier.

Sukaesti, D., Hamid, AYS,.\& Wardani, IY. (2015). Manajemen Asuhan keperawatan Spesialis Jiwa pada Klien Isolasi Sosial dan Risiko Perilaku Kekerasan menggunakan Pendekatan Hubungan Interpersonal Peplau dan Stuart di Ruang Gatotkaca RSMM.Karya Ilmiah Akhir. Fakultas Ilmu Keperawatan Universitas Indonesia. Tidak Dipublikasikan.

Townsend, M.C. (2009). Psychiatric Mental Health Nursing; Concepts of Care in Evidence-Based Practice. $6^{\text {th }}$ Edition. Philadelphia: Davis Plus Company.

Townsend, M.C. (2011). Nursing Diagnoses in Psychiatric Nursing; care Plans and Psychotropic Medication. $8^{\text {th }}$ Edition. Philadelphia: F.A Davis Company.

Videback, S.L. (2011). Psychiatric mental health nursing. $5^{\text {th }}$ edition. Philadhelpia: Lippincott William \& Wilkins. 